Nature, Volume 437, Issue 7056, September $8^{\text {th, }} 2005$ pages 245-248.

\title{
Carbon losses from all soils across England and Wales 1978-2003
}

\author{
Pat H. Bellamy ${ }^{1}$, Peter J. Loveland ${ }^{1}$, R. Ian Bradley ${ }^{1}$, R. Murray Lark ${ }^{2}$ \& Guy J.D. \\ Kirk $^{1^{*}}$
}

\author{
${ }^{1}$ National Soil Resources Institute, Cranfield University, Silsoe, MK45 4DT, UK \\ ${ }^{2}$ Rothamsted Research, Harpenden, AL5 2JQ, UK
}

Most terrestrial carbon is held in soils, more than twice as much as in vegetation or the atmosphere ${ }^{1}$, and changes in soil carbon content can have a large effect on the global carbon budget. The possibility that climate change is being reinforced by increased carbon dioxide emissions from soils with rising temperature is the subject of a continuing debate ${ }^{2-9}$. But to date evidence for the suggested feedback mechanism has come solely from small-scale laboratory and field experiments and modelling studies ${ }^{2-9}$. Here we use data from the National Soil Inventory of England and Wales obtained between 1978 and 2003 to show that carbon was lost from soils across England and Wales over the survey period at a mean rate of 0.6 per cent per year (relative to the existing soil carbon content). We find that the relative rate of carbon loss increased with soil carbon content and was more than two per cent per year in soils with carbon contents greater than 100 grams per kilogram. The relationship between rate of loss and carbon content held across the whole country and across all forms of land use suggesting a link to climate change. Our findings indicate that losses of soil carbon in England and Wales, and by inference other temperate regions, are likely to have been offsetting absorption of carbon by terrestrial sinks.

The National Soil Inventory was made to obtain an unbiased estimate of the distribution of the soils of England and Wales and of the chemistry of the topsoil (0-15 $\mathrm{cm})^{10}$. Samples were collected and soil profiles described at the intersections of an orthogonal 5-km grid over the whole area (Methods). This yielded about 6,000 sites of which 5,662 could be sampled for soil. Figure 1a shows the distribution of soil organic carbon contents across England and Wales measured in the original sampling (1978-83). Sufficient sub-sets of the sites were re-sampled at intervals from 12 to 25 years after the original sampling to be able to detect changes in carbon content with 95\% confidence (Methods). This was done in three phases: in 1994/95 for arable and rotational grassland sites (853 of the original 2,578 sites), in 1995/96 for managed permanent grassland sites (771 of the original 1,579), and in 2003 for non-agricultural sites (bogs, scrub, rough grazing, woodland, etc; 555 of the original 1,505). Roughly $40 \%$ of the original sites were re-sampled. This is the only soil inventory on such a scale anywhere in the world to have been re-sampled. To allow for the varying time interval between samplings, annual rates of change in carbon were calculated for each site by 
assuming that the process of change was linear over the sampling interval. An analysis of known rates of change in soil carbon under different conditions showed this to be reasonable.

Figure 2 summarises the results grouped by soil type and land use. Some differences between soils and land uses are apparent: for example, peat soils lost carbon an order of magnitude faster than brown soils and man-made soils, and bogs and upland grass lost carbon an order of magnitude faster than lowland heath, which appears to have gained carbon on average. But we found no statistically significant relations between rate of change and land use, rainfall class or soil textural class, whether for the data as a whole or for outlying data. However, we found a significant negative linear correlation between rate of change and original organic carbon content $\left(\mathrm{C}_{\text {org }}\right)$, i.e. the rate of loss increased with $\mathrm{C}_{\text {org }}$ (Fig. 3). The relation applied for the data as a whole and for the three main land use groupings separately, though with different slopes and intercepts. We took a random sub-sample of 1000 observations from the data as a whole and obtained the following relation by linear regression specifying an exponential variogram for the residuals (Methods):

Rate of change in $\mathrm{C}_{\text {org }}\left(\mathrm{g} \mathrm{kg}^{-1} \mathrm{yr}^{-1}\right)=0.6-0.0187 \times$ original $\mathrm{C}_{\text {org }}\left(\mathrm{g} \mathrm{kg}^{-1}\right)$

(standard error of intercept $=0.148$ and of slope $=0.00081$ ). The residuals from this regression applied to the whole data set show some regional features, notably a tendency to overestimate the rate of loss in uplands in the north-west and south-west of England. But only $8 \%$ of the unexplained variation is spatially structured, so a more sophisticated statistical model is unjustified. Figure $1 \mathrm{~b}$ shows the distribution of rates of change across England and Wales for all the sites, with values for the sites that were not re-sampled obtained using Equation (1).

From the data in Fig. 3, the relative rates of change (rate of change / mean $\mathrm{C}_{\text {org }}$ over-sampling interval) were $1.43,0.14,-0.69,-1.84,-2.71,-3.01$ and $-2.35 \% \mathrm{yr}^{-1}$ for original $C_{\text {org }}$ ranges 0-20, 20-30, 30-50, 50-100, 100-200, 200-300 and > 300 g kg-1, respectively. Hence the relative rates of loss also tended to increase with $\mathrm{C}_{\text {org }}$, though not above $300 \mathrm{~g} \mathrm{~kg}^{-1}$. Soils with $\mathrm{C}_{\mathrm{org}}<50 \mathrm{~g} \mathrm{~kg}^{-1}$ did not lose significant amounts of carbon (i.e. not detectable over $10 \mathrm{yr}$ ), and those with $\mathrm{C}_{\mathrm{org}}<20 \mathrm{~g} \mathrm{~kg}^{-1}$ appear to have gained it. However, for soils with $\mathrm{C}_{\text {org }}>100 \mathrm{~g} \mathrm{~kg}^{-1}$ relative rates of loss over the survey period were $>2 \% \mathrm{yr}^{-1}$. Given that the bulk of the UK's carbon stocks are in organic soils $^{12}$, this is an alarming result.

Table 1 gives estimates of the total changes in carbon in the upper $15 \mathrm{~cm}$ of soil for the whole of England and Wales, with rates for the sites that were not re-sampled predicted using Equation (1). The total amount in the upper $15 \mathrm{~cm}$ at the time of the original sampling is estimated to be $864 \mathrm{Tg}$ and the total rate of change in this depth is 4.44 $\mathrm{Tg} \mathrm{yr}^{-1}$. From the distribution of soil types in the 1:250,000 National Soil Map interpolated on a 1-km grid, Milne et al. ${ }^{11}$ estimate the total carbon stock of the soils of Great Britain to be 2,458 Tg over 0-30 cm depth (1,404 Tg in England and Wales, $1,153 \mathrm{Tg}$ in Scotland). If the rate of change found here also applies to the soils of Scotland (but note that most soils in Scotland have large organic carbon contents ${ }^{12}$, and therefore the true rate of loss is likely to be larger), and if the rate of change over 0-30 $\mathrm{cm}$ depth is the same as over $0-15 \mathrm{~cm}$, then pro rata the total rate of loss across Great Britain is $12.5 \mathrm{Tg} \mathrm{yr}^{-1}$. For comparison, the UK's current industrial $\mathrm{CO}_{2}$ emission is about $150 \mathrm{Tg} \mathrm{yr}^{-1}$. 
We cannot with the existing data say where the missing carbon has gone. Some proportion will have been emitted to the atmosphere as $\mathrm{CO}_{2}$; some will have been leached to deeper soil layers and to drainage waters and beyond. The latter would be consistent with the observed increases in dissolved organic carbon in surface waters across much of England and Wales over the past 40 years ${ }^{12,13}$.

Soil carbon contents depend on rates of addition from plant growth versus rates of removal in decomposition, leaching and other soil processes, and each of these is sensitive to changes in land use, climate and other variables ${ }^{14-17}$. Various changes in land use will have contributed to carbon losses from soils across England and Wales over the survey period, both under agricultural uses (drainage schemes, post-war grassland conversion, increased stocking rates) and non-agricultural uses (afforestation on wet soils, increased erosion, increased burning of upland vegetation). However we do not have sufficient data at the scale of the National Soil Inventory to explore these effects.

The fact that the losses appear to be happening across the country irrespective of land use suggests a link to climate change. Over the survey period, the mean temperature across England and Wales increased by about $0.5^{\circ} \mathrm{C}$ and there were also changes in rainfall distribution ${ }^{18}$. Climate change will affect soil carbon turnover through various processes. Increases in temperature will tend to increase rates of organic matter decomposition by soil microbes, though the magnitude of this effect and differences between soils are uncertain ${ }^{9}$. The effects of temperature will interact in a complicated way with changes in soil moisture brought about by changing rainfall and evapo-transpiration patterns, and changes in atmospheric $\mathrm{CO}_{2}$ and nitrogen deposition. In freely-drained soils, warmer drier conditions may retard decomposition of organic matter if lack of moisture limits soil microbes. But in wet anoxic soils, increased oxygenation of the soil as evaporation increases the depth to the water table will greatly reinforce the increase in decomposition with increased temperature. Such effects may in part explain the increase in the relative rate of loss with soil carbon content because more-organic soils tend to be wetter. Also consistent with this, more-organic soils necessarily contain a greater proportion of slowly decaying organic matter, and the rate of turnover of this material appears to be more sensitive to temperature changes than that of more-labile organic matter ${ }^{8}$. However the magnitudes of these effects are unknown.

Based on atmospheric observations, net carbon absorption by terrestrial systems in the northern hemisphere has increased in recent decades ${ }^{14}$. The magnitude of the carbon sink in different regions and the contributions of different processes are highly uncertain, but the main sinks are thought to be changes in land use and increased forest growth with increased atmospheric $\mathrm{CO}_{2}$ and nitrogen deposition. Our findings show that losses of soil carbon in the UK and by inference other temperate regions are likely to have been offsetting absorption by terrestrial sinks, greatly adding to the uncertainty of future trends.

\section{Methods}

\section{Original sampling}

The 5-km sampling grid was offset $1 \mathrm{~km}$ north and $1 \mathrm{~km}$ east of the origin of the National Grid to avoid sampling at the edges of published maps. Urban areas and water bodies were avoided, but otherwise all soils were sampled. At each site 25 soil cores were taken at 4-m intervals in a $20 \mathrm{~m}$ x $20 \mathrm{~m}$ square centred on the grid intersection ${ }^{19}$. 
The cores were taken to a maximum depth of $15 \mathrm{~cm}$ from the surface using a $2.5-\mathrm{cm}$ diameter auger, with the soil surface taken as the zero of measurement, and excluding litter layers and living vegetation. The cores were bulked in the field, giving a total of approximately $1 \mathrm{~kg}$ of moist material for each site. The samples were air-dried at temperatures not exceeding $30^{\circ} \mathrm{C}$, and each then divided into three equal portions. One portion was stored in a polythene bag inside a cardboard box at ambient temperature and humidity without further treatment. The other portions were crushed $<2 \mathrm{~mm}$ and sub-samples analysed for organic carbon as below.

\section{Re-sampling}

The minimum proportions of the original sites to be re-sampled so as to detect changes in $\mathrm{C}_{\text {org }}$ with $95 \%$ confidence were calculated using the relation $\frac{n_{2}}{n_{1}} \geq \frac{1}{1+n_{1}\left(d / z_{\alpha} s\right)^{2}}$ where $n_{1}$ and $n_{2}$ are the sizes of the original and re-sampled populations, $\alpha$ is the probability that the change in mean $\mathrm{C}_{\text {org }}$ is greater than some small value $d, z_{\alpha}$ is the probability of the standardised Normal distribution of $\mathrm{C}_{\text {org }}$ being less than $\alpha$, and $s$ is the standard deviation of the original population. The accuracy of the $\mathrm{C}_{\text {org }}$ measurement in the laboratory (below) was $\pm 1 \mathrm{~g} \mathrm{~kg}^{-1}$ and hence the minimum value of $d$ is $2 \mathrm{~g} \mathrm{~kg}^{-1}$. This value was used for the arable/rotational grass and permanent grass sites. For the non-agricultural sites, the standard deviation of $\mathrm{C}_{\text {org }}$ was greater, particularly for moreorganic soils. Accordingly for these sites sampling was designed with $d=2 \mathrm{~g} \mathrm{~kg}^{-1}$ for soils with $\mathrm{C}_{\text {org }}<150 \mathrm{~g} \mathrm{~kg}^{-1}, d=5 \mathrm{~g} \mathrm{~kg}^{-1}$ for $\mathrm{C}_{\text {org }}=150-300 \mathrm{~g} \mathrm{~kg}^{-1}$ and $d=10 \mathrm{~g} \mathrm{~kg}^{-1}$ for $\mathrm{C}_{\text {org }}>300 \mathrm{~g} \mathrm{~kg}^{-1}$. Sites were selected at random from the original sites within these groupings in proportion to the original regional sampling density, and sampled exactly as originally.

To test the accuracy with which the sites could be relocated, six surveyors were instructed to re-visit 10 sites with widely differing characteristics following the originally recorded site descriptions, their positions recorded with a global positioning system, and the distances between them subsequently measured. This showed the accuracy of re-location was better than $20 \mathrm{~m}$ on enclosed land and better than $50 \mathrm{~m}$ on open land, and values of $\mathrm{C}_{\text {org }}$ at 0,20 and $50 \mathrm{~m}$ from the target measured using the original methods were not significantly different from each other (Supplementary Fig. 1). Hand-written field records from the original sampling were examined to see if outliers in the data (based on the log normalised changes in $\mathrm{C}_{\text {org }}$ ) had any common features. No artefacts were found that would have led us to believe the outliers were not true representations of the changes.

\section{Organic carbon analysis}

Exactly the same methods were used for the two samplings. Soils with $\mathrm{C}_{\text {org }}<$ approx. $150 \mathrm{~g} \mathrm{~kg}^{-1}$ were analysed by a modified Walkley-Black method ${ }^{20}$. The small subsamples this uses are unrepresentative of highly organic soils, so soils with $\mathrm{C}_{\text {org }}>$ approx. $150 \mathrm{~g} \mathrm{~kg}^{-1}$ were analysed by loss on ignition (LOI) ${ }^{21}$, converted to $\mathrm{C}_{\text {org }}$ by $\mathrm{C}_{\text {org }}=$ $0.5 \times$ LOI. To check that the change of method introduced no artefacts, we applied both to 95 soils with $\mathrm{C}_{\text {org }}=20-200 \mathrm{~g} \mathrm{~kg}^{-1}$ and obtained good agreement and no systematic deviation (Supplementary Fig. 2). To check for differences in analytical precision between the samplings, we re-analysed stored samples from $10 \%$ of the original sites and obtained good agreement with the original values across the full range of $\mathrm{C}_{\text {org }}$ (Supplementary Fig. 3). 


\section{Derivation of Equation (1)}

Equation (1) is a regression, but was not fitted by ordinary least squares because the original systematic sampling precludes the assumption that the residuals are independent random variables ${ }^{22}$. The Equation (1) was fitted as a mixed model with a spatially-dependent random effect and a white noise term such that, for any pair of locations $\mathbf{x}_{i}$ and $\mathbf{x}_{j}$ the expected squared difference of the residuals, $\eta\left(\mathbf{x}_{i}\right)$ and $\eta\left(\mathbf{x}_{j}\right)$, is $\mathrm{E}\left[\left\{\eta\left(\mathbf{x}_{i}\right)-\eta\left(\mathbf{x}_{j}\right)\right\}^{2}\right]=2\left\{c_{0}+c_{1}\left(1-\exp \left[-\left|\mathbf{x}_{i}-\mathbf{x}_{j}\right| / a\right)\right\}\right.$ where $c_{0}$ and $c_{1}$ are the variances of the white noise and spatially dependent components respectively and $a$ is a distance parameter. The model was fitted by residual maximum likelihood ${ }^{23}$.

1. Batjes, N.H. Total carbon and nitrogen in the soils of the world. Eur. J. Soil Sci. 47, 151-163 (1996).

2. Jenkinson, D.S., Adams, D.E. \& Wild,A. Model estimates of $\mathrm{CO}_{2}$ emissions from soil in response to global warming. Nature 351, 304-306 (1991).

3. Cao, M.K. \& Woodward, F.I. Dynamic responses of terrestrial ecosystem carbon cycling to global climate change. Nature 393, 249-252 (1998).

4. Giardina, C.P. \& Ryan, M.G. Evidence that decomposition rates of organic carbon in mineral soil do not vary with temperature. Nature 404, 858-861 (2000).

5. Cox, P.M., Betts, R.A., Jones, C.D., Spall, S.A. \& Totterdell, I.J. Acceleration of global warming due to carbon-cycle feedbacks in a coupled climate model. Nature 408, 184-187 (2000).

6. Davidson, E.A., Trumbore, S.E. \& Amundson, R. Soil warming and organic carbon content. Nature 408, 789-790 (2000).

7. Fang, C., Smith, P., Moncrieff, J.B. \& Smith, J.U. Similar response of labile and resistant soil organic matter pools to changes in temperature. Nature 433, 57-59 (2005).

8. Knorr, W., Prentice, I.C., House, J.I. \& Holland, E.A. Long-term sensitivity of soil carbon turnover to global warming. Nature 433, 298-301 (2005).

9. Powlson, D.S. Will soil amplify climate change? Nature 433, 204-205 (2005).

10. Loveland, P.J. The National Soil Inventory: Survey design and sampling strategies. Pages 73-80 in H. Lieth \& B. Markert (eds) Element Concentration Cadasters in Ecosystems. VCH Verlagsgesellschaft, Weinheim, Germany (1990).

11. Milne, R., Bradley, R.I., Jordan, C. \& Brown, T.A.W. Development of an improved version of the soil carbon inventory for the UK LULUCF GHG Inventory. Chapter 6 in R. Milne \& D.C. Mobbs (eds) UK Emissions by Source and Removals by Sinks due to Land Use, Land Use Change and Forestry Activities. Final Report of Defra Project GA01054. Defra, London (2004).

12. Worrall, F., Burt, T. \& Shedden, R. Long term records of riverine dissolved organic matter. Biogeochemistry 64, 165-178 (2003).

13. Freeman, C. et al. Export of dissolved organic carbon from peatlands under elevated carbon dioxide levels. Nature 430, 195-198 (2004).

14. Schimel, D.S. et al. Recent patterns and mechanisms of carbon exchange by terrestrial ecosystems. Nature 414, 169-172 (2001).

15. Guo, L.B. \& Gifford, R.M. Soil carbon stocks and land use change: a meta-analysis. Glob. Change Biol. 8, 345-360 (2002). 
16. Houghton, R.A. Revised estimates of the annual net flux of carbon to the atmosphere from changes in land use and land management 1850-2000. Tellus $B$ 55, 378-390 (2003).

17. Smith, K.A. et al. Exchange of greenhouse gases between soil and atmosphere: interactions of soil physical factors and biological processes. Eur. J. Soil Sci. 54, 779-791 (2003).

18. Hulme, M. et al. Climate Change Scenarios for the United Kingdom: The UKCIPO2 Scientific Report. Tyndall Centre for Climate Change Research, Norwich, UK (2002).

19. Webster R. \& Burgess T.M. Sampling and bulking strategies for estimating soil properties in small regions. J. Soil Sci. 35, 127-140 (1984).

20. Kalembara, S.J. \& Jenkinson, D.S. A comparative study of titrimetric and gravimetric methods for the determination of organic carbon in soil. J. Sci. Food Agric. 24, 1085-1090 (1973).

21. Avery, B.W. \& Bascomb, C.L. Soil Survey Laboratory Techniques. Soil Survey Technical Monograph No. 6. Soil Survey of England \& Wales, Harpenden (1974).

22. Lark, R.M. \& Cullis, B.R. Model-based analysis using REML for inference from systematically sampled data on soil. Eur. J. Soil Sci. 55, 777-797 (2004).

23. Gilmour, A.R. et al. ASReml User Guide release 1.0. VSN International Ltd., Hemel Hempstead (2002).

24. Avery, B.W. Soil classification for England and Wales (Higher categories). Soil Survey Technical Monograph No.14. Soil Survey of England \& Wales, Harpenden (1980).

25. Howard, P.J.A. et al. The carbon content of soil and its geographical-distribution in Great Britain. Soil Use Manage. 11, 9-15 (1995).

\section{Acknowledgements}

We thanks Defra for funding this research, Richard Andrews for technical assistance, and David Powlson and John Hollis for comments on the draft Letter. 
Figure legends

Figure 1 Changes in soil organic carbon contents across England and Wales between 1978 and 2003. (a) Carbon contents in the original samplings and (b) rates of change calculated from the changes over the different sampling intervals. Values at sites that were not re-sampled were calculated from their original organic carbon contents using Equation (1). The changes were negative in all but $8 \%$ of the sites.

Figure 2 Rates of change in soil organic carbon content grouped by (a) soil type (defined by Avery ${ }^{24}$ ) and (b) land use. Circles indicate mean values; error bars indicate $95 \%$ confidence intervals.

Figure 3 Rates of change in soil organic carbon content grouped by original carbon contents and indicated land uses. The ranges of carbon content are, from left to right in each panel, 0-20, 20-30, 30-50, 50-100, 100-200, 200-300 and $>300 \mathrm{~g} \mathrm{~kg}^{-1}$. Bar heights indicate mean values; error bars indicate $95 \%$ confidence intervals. The derivation of Equation (1) is described in the text. 
Fig. 1

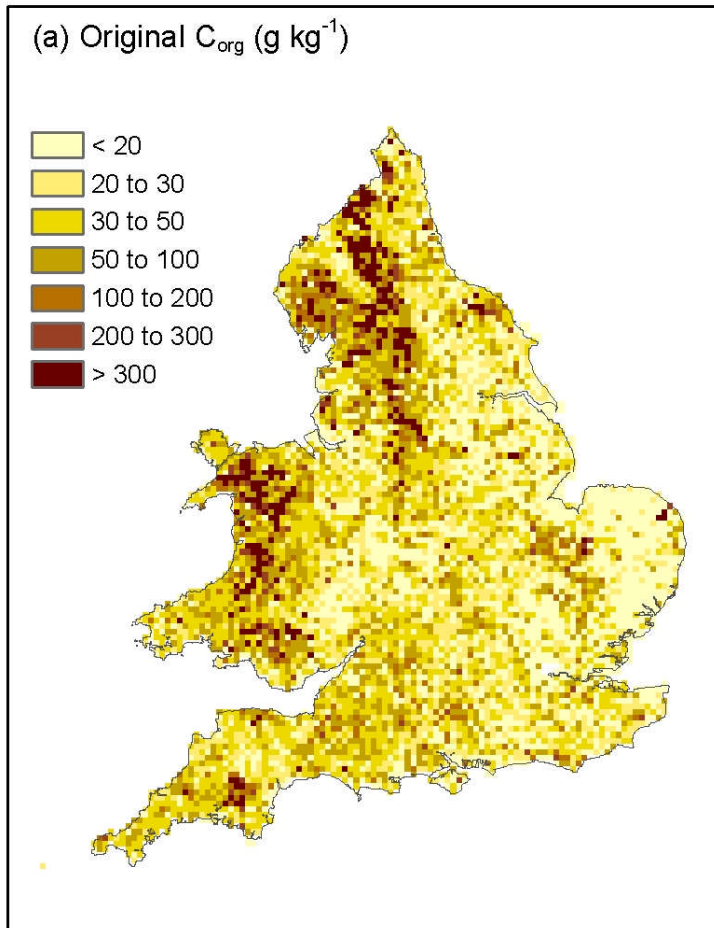

(b) Rate of change $\left(\mathrm{g} \mathrm{kg}^{-1} \mathrm{yr}^{-1}\right)$
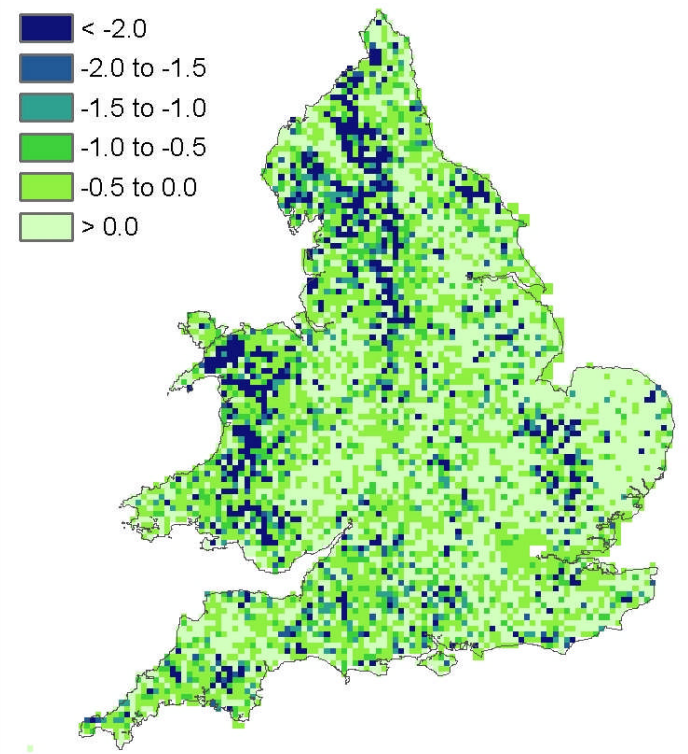
kirk-fig2

(a) Soil type

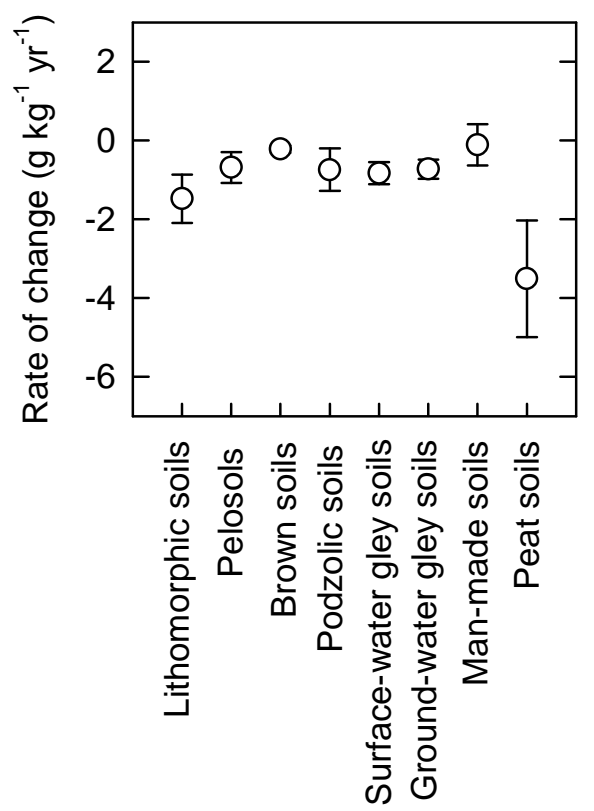

(b) Land use

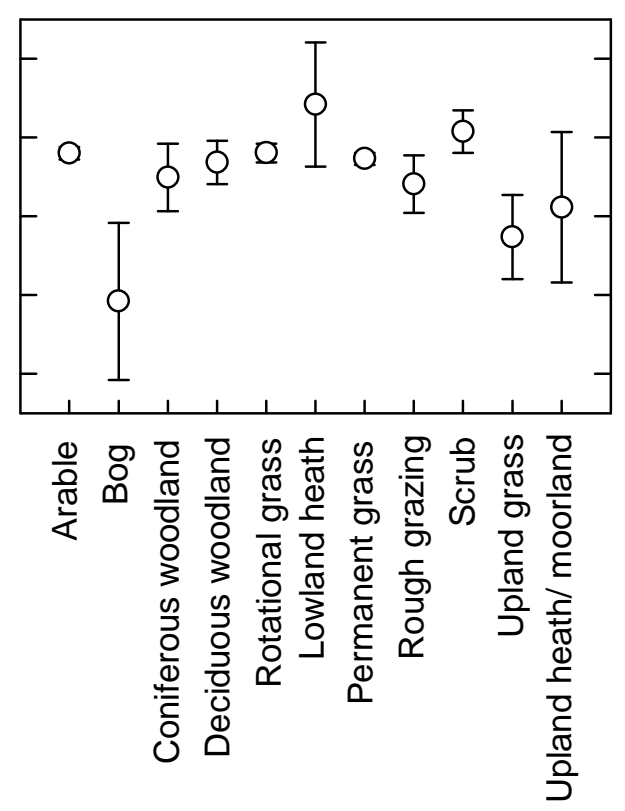


kirk-fig3

(a) Arable/ rotational grass

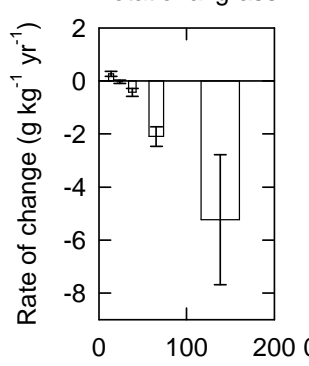

(b) Permanent grass

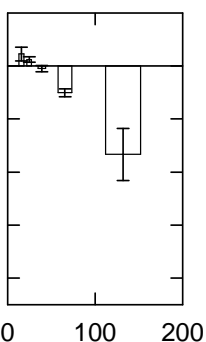

(c) Non-agricultural

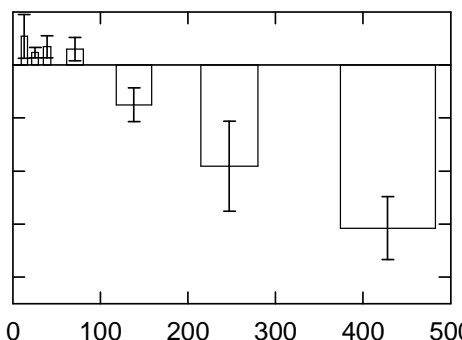

(d) All

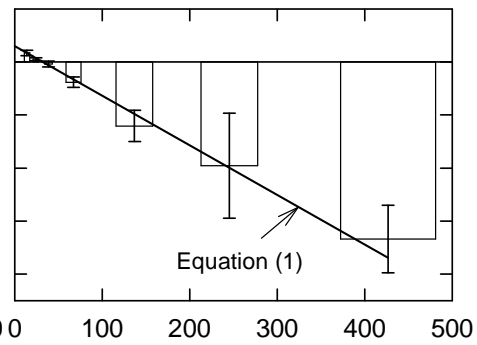

Organic carbon content $\left(\mathrm{g} \mathrm{kg}^{-1}\right)$ 
Table 1 Estimated rates of change for all original sites

\begin{tabular}{|c|c|c|c|c|c|c|c|c|}
\hline \multirow{2}{*}{$\begin{array}{c}\text { Range of } \\
\text { original } \\
\mathrm{C}_{\text {org }} \\
\left(\mathrm{g} \mathrm{kg}^{-1}\right)\end{array}$} & \multirow[t]{2}{*}{$\begin{array}{l}\text { No. sites } \\
\text { originally } \\
\text { sampled }\end{array}$} & \multirow{2}{*}{$\begin{array}{c}\text { Mean } \\
\text { original } \\
\mathrm{C}_{\text {org }} \\
\left(\mathrm{g} \mathrm{kg}^{-1}\right)\end{array}$} & \multicolumn{2}{|c|}{ Total area } & \multicolumn{2}{|c|}{$\begin{array}{c}\text { Total } \mathrm{C}_{\text {org }} \\
0-15 \mathrm{~cm} \\
\text { depth }^{\mathrm{a}}\end{array}$} & \multirow{2}{*}{$\begin{array}{c}\text { Rate of } \\
\text { change in } \\
\mathrm{C}_{\mathrm{org}} \\
\left(\mathrm{g} \mathrm{kg}^{-1} \mathrm{yr}^{-1}\right)\end{array}$} & \multirow{2}{*}{$\begin{array}{c}\text { Total } \\
\text { change } \\
\text { in } 0-15 \\
\mathrm{~cm}^{\mathrm{c}} \\
\left(\mathrm{Tg} \mathrm{yr}^{-1}\right)\end{array}$} \\
\hline & & & $\left(\mathrm{km}^{2}\right)$ & $(\%)$ & $(\mathrm{Tg})$ & $(\%)$ & & \\
\hline 0-20 & 1,061 & 13.9 & 26,525 & 18.7 & 66.4 & 7.7 & 0.34 & 1.68 \\
\hline $20-30$ & 1,158 & 24.5 & 28,950 & 20.5 & 111.9 & 12.9 & 0.13 & 0.66 \\
\hline $30-50$ & 1,607 & 38.5 & 40,175 & 28.4 & 214.8 & 24.9 & -0.10 & -0.65 \\
\hline 50-100 & 1,140 & 66.8 & 28,500 & 20.1 & 220.5 & 25.5 & -0.68 & -2.11 \\
\hline $100-200$ & 313 & 137.6 & 7,825 & 5.5 & 92.5 & 10.7 & -2.18 & -1.32 \\
\hline $200-300$ & 95 & 244.5 & 2,375 & 1.7 & 36.5 & 4.2 & -4.00 & -0.59 \\
\hline$>300$ & 288 & 439.7 & 7,200 & 5.1 & 121.7 & 14.1 & -7.37 & -2.10 \\
\hline All & 5,662 & 66.1 & 141,550 & 100 & 864.3 & 100 & -0.64 & -4.44 \\
\hline
\end{tabular}

a original $\mathrm{C}_{\text {org }} \times$ bulk density $\left(\mathrm{kg} \mathrm{dm}^{-3}\right) \times$ depth $(\mathrm{dm}) \times$ area $\left(\mathrm{km}^{2}\right) \times 10^{-4}$, where bulk density $=1.3-\left(0.275 \ln \left(\mathrm{C}_{\text {org }} / 10\right)\right)^{(25)}$

${ }^{b}$ for sites not re-sampled, rate of change calculated from original $C_{o r g}$ using Equation (1)

crate of change $\times$ bulk density $\times$ area 